\title{
LGBTIQTeens - Plugged in and Unfiltered: How Internet Filtering Impairs Construction of Online Communities, Identity Formation, and Access to Health Information
}

David Brian Holt

Santa Clara University School of Law, dholt@scu.edu

Follow this and additional works at: http://digitalcommons.law.scu.edu/librarian

Part of the Library and Information Science Commons

\section{Recommended Citation}

Holt, David B. "LGBTIQ teens - plugged in and unfiltered: how internet filtering impairs construction of online communities, identity formation, and access to health information", chapter in Serving LGBTIQ library and archives users : essays on outreach, service, collections and access. Greenblatt, editor. McFarland Publishers (2010) 
Running head: GAY TEENS - PLUGGED IN AND UNFILTERED

LGBTIQ Teens - Plugged In and Unfiltered: How Internet Filtering Impairs Construction of Online Communities, Identity Formation, and Access to Health Information

David Brian Holt 


\section{Introduction}

The LGBTIQ community has a special relationship with the Internet. A number of studies have suggested that LGBTIQ people are more likely to use the Internet as an information resource than other patron groups. They are also more actively engaged in social media and online social networking (Harris Poll Interactive, 2008). They are more likely to be tech savvy and use the Internet to access information about health concerns, sexuality, and mental health. Consequently, the Internet has become a vital resource within the LGBTIQ community to access information crucial to community health and well-being. This is particularly true for LGBTIQ adolescents who must often contend with a hostile and homophobic environment and an insufficient social network. In response, the Internet has played a vital role in helping LGBTIQ adolescents reach out to other young people like themselves and to form online social networks that address their unique information and social needs. These social networks can act as a support system to help adolescents navigate the troubled waters of identity formation and the unique issues associated with adolescence among LGBTIQ youth.

The anonymity the Internet provides represents an invaluable resource where LGBTIQ youth can freely discuss their issues, concerns and problems without fear of reprisal from a frequently homophobic community. LGBTIQ youth may find the Internet, and its online communities and social networks, to be the only conduit through which they can express themselves, reach out to others, and access health information that addresses their particular issues and needs. LGBTIQ adolescents often deal with environments that lack sufficient social networks, such as empathetic adults or friends, and they may face daily discrimination due to their sexual orientation or gender expression.

The mandated use of Internet filtering in public libraries, however, threatens this special relationship. With the passage of CIPA (Children's Internet Protection Act), and its 
constitutionality subsequently affirmed by the Supreme Court, libraries are faced with the challenges presented by Internet filtering, and the obstacles to access it creates for disadvantaged patron groups. While library science literature has frequently discussed the problems of Internet filtering, LGBTIQ adolescents are often neglected by these studies despite filtering having a disproportionate impact on their communities. The need for anonymity, which the Internet can provide, is a more crucial need for LGBTIQ youth who often must construct their social networks in an environment hostile to their emotional, social and informational needs.

\section{Internet usage among LGBT adolescents}

In order to understand the implication of Internet filtering, it is important to recognize the significance of Internet use among all youth. In 2002, a study conducted by the Kaiser Family Foundation found that 74 percent of adolescents between the ages of 15 and 17 reported having Internet access at home, with 31 percent having access in their bedrooms (Rideout, 2002, p. 2). Along with an increasing reliance on the Internet in general, adolescents have increased their use of online resources to answer their health questions. In fact the Kaiser study found that some 70 percent report they have used the Internet as a health information resource (p. 4). Among these, 50 percent were found to use the Internet for information on general health topics such as cancer or diabetes, with 40 percent also using it for information about sexual health topics ranging from teen pregnancy and birth control to STD transmission. For issues such as depression and mental illness, 23 percent reported using the Internet as an information resource. The Internet ranked higher as a resource for health information above even friends (23 percent), or TV shows/movies (17 percent). When asked what made the Internet such an important resource, the most frequent response was its privacy and confidentiality. This element of confidentiality played a key role in the reason why adolescents felt comfortable using the Internet to access this information, with 82 
percent reporting it as the most important reason in using the Internet as a health resource (p. 12). The results of the study suggest, therefore, that the Internet is increasingly vital for adolescents seeking out health and sexuality information they may be reluctant or unable to access via other means. The importance of privacy may also encourage adolescents to choose to use a library Internet connection rather than one available at home, as they may be under the impression that a public terminal will not keep a record of where they go online. According to the Kaiser report, 58 percent of adolescents reported not being concerned that their online activity would be documented on terminals available at their school or library (p. 13). Of course, public terminals at libraries are also outside the view of parents that may be a major concern for LGBTIQ youth struggling with their identity formation.

\section{Social networking on the Internet}

The anonymity provided by the Internet creates a unique resource for LGBTIQ teens looking to find peers with similar experiences. Gay teens may use the Internet to "try out" an identity before they ascribe to one themselves. The Internet, therefore, gives gay teens the unique opportunity to "prepare, discuss, and shape their gay identities before trying them out in real space" (Bernstein, 2004, p. 1026). Social networking sites, such as MySpace and Facebook, or virtual environments such as Second Life ${ }^{1}$, permit teens to construct an online identity without the same risk of community reprisal and enable these adolescents to connect with others who are constructing similar identities. Accordingly, the Internet is playing an increasingly important role in the "coming-out" process for these gay teens, enabling them to come out in an environment with little or no social consequences before they do so in "real space" (McKenna, Bargh, 1998, p. 686). Of course, the Internet is not free from social consequences as cases of "cyber-bullying" and online harassment demonstrate ${ }^{2}$. However, for a teen who truly desires 
total anonymity and confidentiality for their identity construction, the Internet can provide this avenue in ways that "real-life" cannot.

This coming-out process, done online, may be conducive to the mental health of LGBTIQ adolescents. Frequently, sexual minority or gender variant teens must deal with an environment where they feel marginalized and different from others. This may be particularly true in rural or conservative environments where there are few local resources for LGBTIQ adolescents. By finding other LGBTIQ youth on the Internet, a teen may experience a “demarginalization" of their sexual or gender identity and have reduced feelings of isolation (McKenna, Bargh, 1998, p. 691; Munt, Bassett, O’Riordan, 2002, p. 135). An online environment also allows teens to experiment in forming their identity as they navigate the stresses of adolescence. By creating an online identity before they came out to their "real-life" friends, gay teens are "motivated to come back to real life with their Internet life to verify their identity and make it 'real'” (McKenna, Bargh, 1998, p. 692).

The process of forming an identity online, rather than in "real-life", may also translate into lower rates of risk for these LGBTIQ teens as they are not forced into adult environments they are ill equipped to handle (Bernstein, 2004, p. 1027). With the Internet, these adolescents are able to socialize with their peers and do so rather safely and without the same degree of risk that they will be forced into environments, or relationships, they are ill-equipped to handle. It is thus particularly ironic that the legislative intent of mandated Internet filtering is to protect teens when it pushes them into environments with greater risk of harm.

\section{LGBTIQ Internet revolution}

That the Internet is playing an enormous role in the lives of LGBTIQ adolescents perhaps cannot be overstated. As the Internet moves from a Web 1.0 to a 2.0 environment with an 
increase in interactivity and social interaction, the ways in which LGBTIQ adolescents use online resources and communities have changed dramatically. LGBTIQ youth, particularly in conservative and rural communities, are able to connect with their peers and meet their unique socialization needs in ways that were impossible just a few years ago.

A recent Harris Interactive poll finds that LBGTIQ people use online social networking tools at a higher rate than their similarly situated heterosexual peers (Harris Poll Interactive, 2008, p. 1). The survey found that $55 \%$ of LGBTIQ adults are on Facebook compared with $46 \%$ of adult heterosexuals. Further, 20\% of LGBTIQ adults had a Twitter account, compared with only $12 \%$ of heterosexuals. This disparity between LGBTIQ Internet users, and their heterosexual peers, is perhaps even more pronounced among adolescents although quantitative studies of this group are hard to acquire given that many LGBTIQ adolescents are still in the process of identity formation.

This reliance on the Internet is also reducing the age at which LGBTIQ adolescents are navigating their identities. Journalist Benoit Denizet-Lewis, who formerly worked for the popular gay teen magazine "XY", wrote an article for the New York Times that discusses how LGBTIQ adolescents are coming-out at younger ages (2009). There appears to be a generation gap emerging within the larger LGBTIQ community as the "coming-out" process is started at a much younger age. He attributes this shift to not only a decreasingly homophobic culture, but also from the identity-formation taking place in online communities. He writes that: "[G]ay teenagers...still suffer harassment at school or rejection at home, but many [seem] less burdened with shame and self-loathing than their older gay peers. What had changed? Not only were there increasingly accurate and positive portrayals of gays and lesbians in popular culture, but most teenagers were by then regular Internet users. Going online broke through the isolation that had been a hallmark of being young and gay, and it allowed gay teenagers to find information to 
refute what their families and churches sometimes still told them - namely, that they would never find happiness and love" (Denizet-Lewis, 2009, p. 1).

\section{The unique information needs of sexual minority youth}

A study commissioned by the Gay, Lesbian Straight Education Network (GLSEN) on the online behavior of LGBTIQ adolescents found that 68 percent of respondents revealed that being online helped them to accept their sexual orientation, with 51 percent calling the Internet "crucial" to that acceptance (Garry et al., 1999, p. 20). The American Psychological Association (APA) recognizes that "coming-out" is conducive to mental health and is an important step towards the acceptance of one's sexuality and personal development. Additionally, the APA strongly recommends the inclusion of homosexuality and other LGBTIQ issues in sex education curriculum, and that access to important health and sexuality information is available to adolescents. In their statement on sexual orientation, the APA asserts that "the process of identity development for lesbians, gay men and bisexuals called 'coming out,' has been found to be strongly related to psychological adjustment - the more positive the gay, lesbian, or bisexual identity, the better one's mental health and the higher one's self-esteem" (APA, 2009, p. 1). This stronger sense of self also translates into making informed and wiser decisions about health, sexuality and gender expression.

Because the Internet plays this vital role in disseminating health and sexuality information, it is essential to understand the unique impact it has on the lives of sexual minority youth in particular. Interestingly, one study that attempted to measure the online informationseeking behavior of sexual minority youth indicated that 51 percent admit they revealed their sexual orientation to someone online before their friends or family (Garry et al., 1999). Other studies have found similar results indicating that LGBTIQ adolescents are heavy users of the 
Internet in comparison to their non-LGBTIQ peers (Koswic, Diaz, Greytak, 2007; Brooks, 2009). These statistics highlight the importance of Internet use among LGBTIQ youth,

effectively demonstrating the importance of their ability to build communities in which they can discuss their particular concerns and issues. Building a social network of support and community is vital to mental health and social development, ultimately allowing adolescents to make informed choices about their health.

\section{Identify formation in an online environment}

Besides providing valuable health information and social networking, the Internet also plays a vital role in the formation of identity for LGBTIQ adolescents. Given that many of these young people live in environments which may not be conducive to the formation of their sexual orientation or gender expression, it is critically important that they find a safe, and affirming, place where they can explore and form their identity just like their non-minority peers. Unlike their peers, however, LGBTIQ adolescents must reveal their identity to receive appropriate support and may find hostility, or social stigmatization, by doing so (Friedman, Morgan, 2009, p. 921). The Internet, therefore, provides a safer environment where these adolescents can explore their identities without the same fear of social rejection.

Research indicates that sexual minority and gender variant adolescents who are able to find a supportive social network often have improved outcomes later in life including higher selfesteem, life satisfaction and lower rates of depression (p. 921). Social scientists have suggested that many adolescents negotiate two "master narratives" of sexual identity in the course of their development - "struggle” and "success" (Hammack, Thompson, Pilecki, 2009, p. 867). The first master narrative describes the period where sexual minority adolescents struggle with their external, and internal, challenges to their identity formation. The "success" element is usually 
typified by a "coming-out" experience where the adolescent identifies as LGBTIQ.

Recent social science studies indicate that many contemporary LGBTIQ adolescents are rejecting the identity "options" that were available to their predecessors. Termed "emancipation," this narrative of sexual identity and gender variance reflects the shifting discourse within the LGBTIQ community and the influence of Queer Theory, which frequently argued for a "critical perspective on society's need to create a sexual typology to regulate sexual desire" (p. 868). Some in the LGBTIQ community feel there is a need to reevaluate the sexual taxonomies which define them and replace them with more inclusive terms, reflecting the diversity of sexual desires and identities within the larger community (Hostetler, Herdt, 1998, p. 251).

The adolescent LGBTIQ community has readily adopted this "emancipation" from previous sexual taxonomies. Benoit Denizet-Lewis in his article, "Coming Out in Middle School" describes how adolescents are abandoning terms such as "gay" and "lesbian" and are creating their own vocabulary to describe their same-sex desires and gender expression.

Denizet-Lewis describes a group of middle school students who use the term "woof" to describe their peers who have same-sex desires and how identifying as bisexual gives adolescents greater freedom to explore their gender and sexual identities (2009).

\section{Legal history of Internet filtering}

The controversy regarding Internet filtering software in public libraries did not begin with the passage of CIPA. Although the library science literature tends to focus on CIPA, the fight against Internet filtering in public libraries actually started back in 1996. The Communications Decency Act of 1996 (CDA) was introduced in Congress as Title V of the Telecommunications Act of 1996, Pub.L. 104-104, 110 Stat. 133 (1996). The legislation intended to serve two 
functions: first, it aimed to restrict "indecency" available to minors, and secondly to restrict "obscenity". The legislation is also quite notable in that Section 230 releases Internet Service Providers (ISP) and hosting companies of liability for the content published on their sites by users (see 47 U.S.C. $§ 230$ ).

First Amendment advocates quickly challenged the Communications Decency Act (CDA) in court on the rationale that it unconstitutionally infringed upon the free speech rights of adults. Just a year after its passage, the Supreme Court upheld a decision by the Eastern District Court of Pennsylvania that ruled the act unconstitutional as it was overly broad, extended into non-commercial speech and did not define the term "patently offensive," ACLU v. Reno, 929 F.Supp. 824 (E.D.Pa. 1996). The court left intact Section 230 of the act, which continues to indemnify web-hosting companies from liability for the content posted by their users.

The next attempt by Congress to restrict minors' access to materials they deemed "pornographic" was the Child Online Protection Act (COPA), Pub.L. 105-277, 112 Stat. 2681736 (1998). This legislation is not to be confused with the Children's Online Privacy Protection Act, Pub.L. 105-277, 112 Stat. 2681-728 (1998), which requires websites to acquire parental consent when their sites are being used by those aged twelve and under. COPA attempted to prohibit access by minors to materials it calls "harmful" and was written to overcome the court's challenges to CDA. The definition used relied heavily upon community standards to define what is "harmful" using the test developed by Miller v. California, 413 U.S. 15 (1973). The courts quickly enjoined, and eventually overturned, the law for violating free speech guarantees and for applying the community standards test for online material. The court claimed that "COPA essentially requires that every Web publisher subject to the statute abide by the most restrictive and conservative state's community standards in order to avoid criminal liability...[and] imposes an impermissible burden on constitutionally protected First Amendment speech", ACLU v. 
Reno, 217 F.3d 162, 166 (2000). Interestingly, the court claimed that filtering was a narrower means to achieve the goals of restricting minors from accessing pornography than the method COPA provided (Dobija, 2007, p. 52).

At issue with many of these cases is how speech can be regulated on government-owned property. Historically, the courts have organized government property into three types of "forums" when considering issues of free speech therein: traditional public, limited public and non-public forums (Bell, 2001, p. 200; Chemerinsky, 2006, p. 1126). This three-tier system of regulating speech on government-owned property was articulated in the case Perry Education Association v. Perry Local Educators' Association, 460 U.S. 37 (1983). Traditional public forums are public spaces that have been used for free speech activities either by tradition or government fiat. Some examples of traditional public forums include public streets and government-owned parks. In these traditional public forums, the government may not prohibit communicative activity and can only enforce restrictions if they serve a compelling government interest and are narrowly-tailored to further that interest (p. 45). This is similar to the "strict scrutiny" standard courts use to evaluate statutes which infringe upon a fundamental right, or affect a suspect class.

Limited public forums are those government-owned spaces reserved for a particular type of expression. The government may choose to close these limited public forums and they may designate them to be used by specific groups or to discuss particular topics (Bell, 2001, p. 202; Chemerinsky, 2006, p. 1137). Examples of limited public forums include public museums and public libraries. In these forums, "a state is not required to indefinitely retain the open character of the facility, as long as it does so it is bound by the same standards as apply in a traditional public forum. Reasonable time, place and manner regulations are permissible, and a contentbased prohibition must be narrowly drawn to effectuate a compelling state interest" (Perry 
Education Association v. Perry Local Educators' Association, 1983). This standard is similar to the "rational basis" review used by the courts.

One of the most important cases regarding filtering, and what type of forums public libraries should be designated took place in 1997 with the Mainstream Loudoun v. Loudon County case in Virginia, 24 F. Supp. 2d 552 (E.D. Va. 1998). In this case, the court found that filtering infringed upon protected speech when it applied to both adolescent and adult library patrons. It also found that public libraries exist as a limited public forum. In response to this decision, the legislative push for Internet filtering directed its focus specifically on adolescents. In 1998, Senator John McCain introduced the Internet School Filtering Act, which ultimately languished in committee and never came to a vote on the floor (Garry et al., 1999). During the same time, challenges against the Child Online Protection Act (COPA) continued, with the ACLU winning a preliminary injunction against it in February 1999.

Congress responded to these constitutional challenges with the introduction of the Children's Internet Protection Act (CIPA) in 1999 (Pub.L. 106-554, 114 Stat. 2763, 2763A-335). Senators John McCain and Ernest Hollings introduced the bill and it was signed into law by then President Clinton as part of a larger communications-spending bill. CIPA mandates that public libraries that receive funds through federal programs designed to offset their Internet costs must also install filters on their publically available terminals. It includes libraries receiving discounts through the E-rate program, schools that use Elementary and Secondary Education Act of 1985 funds to purchase computers, and libraries which receive federal grants from the Museum and Library Services Act. Ironically, these federal programs were designed with the intent to alleviate the "digital divide" between communities that enjoy high rates of Internet access and less-affluent communities that struggle in providing access.

CIPA was quickly challenged by the American Library Association, with the assistance 
of the American Civil Liberties Union. After an initial success in federal circuit court, the U.S. Supreme Court heard the case and found that CIPA does not impermissibly infringe upon First Amendment speech so long as adult library patrons can have their Internet access unfiltered at their request, U.S. v. ALA, 539 U.S. 194 (2003). The court was unconvinced that filtering's history of overblocking was a concern due to the "ease with which patrons may have filtering software disabled" (p. 196). Furthermore, it found that CIPA did not compel librarians to infringe upon their patrons' First Amendment freedoms.

\section{How does filtering work?}

Filtering software has undergone considerable change since the passage of CIPA back in 1999. Many of the criticisms directed towards filtering software, such as over- and underblocking, have improved over the past decade. The problems still exist, however, as filtering software continues to trail behind web content and the various methods users engage in subverting it. The Brennan Center for Justice at New York University's School of Law has published a public policy report on Internet filtering software and its rates of over- and underblocking. Published in 2006, the report indicates that filtering software continues to fail to meet its promised goals and prevents access to non-objectionable materials while also failing to block "obscene" materials (Heins, 2006, p. 9-39). Additionally, the San Jose Public Library recently

published a report on the effectiveness of filtering software and evaluated the major commercial options including Barracuda, CyberPatrol, FilterGate and WebSense (Houghton-Jan, 2008, p. 9$14)$.

The major technologies used by filtering programs can be divided into several major categories: network-based or stand-alone options, filtering by URL or keyword, blocking what the user sees, blocking by file type, and classification of URLs and keywords (Houghton-Jan, 
2008, p. 3-4). A network-based or stand-alone option is a filter that blocks the terminal used by a patron from requesting forbidden content over the network. If the program deems the content objectionable, then the system never makes a request for it over the Internet.

The second technology, filtering by URL or keyword, is particularly problematic and has a troubled history when it comes to LGBTIQ materials. These filters contain lists of terms that the filtering companies deem likely objectionable. "When the filtering program is in use on a computer, each Internet search result or direct entry of a web address is scanned against the list before results are displayed" (p. 3). Filtering software products have had terms on their keyword list that are particularly troubling. There have been cases of the word "breast" or "lesbian" appearing on these lists, which obviously significantly impair the ability for teens to access important health information or online LGBT communities.

\section{Responding to mandated filtering}

When left with no other choice, libraries may be forced to use these commercial filtering products and struggle in constructing a practices policy which conforms with the principles of making "available the widest diversity of views and expressions, including those that are unorthodox, unpopular, or considered dangerous by the majority" (ALA Freedom to Read, 2009, p. 1). In effect, filtering products that restrict access to topics such as sexual and gender minority issues are doing so because they deem them controversial. This, of course, represents a value judgment on the part of these filtering companies and goes beyond what is required for CIPA compliance. Perhaps revealingly, there exists an established link between many of the popular filtering products (such as Symantec's I-Gear, N2H2's Bess, 836Technologies' X-Stop, Solid Oak Software's Cybersitter, and WebSense) and largely Christian organizations, including prominent positions on the boards of several of the largest filtering companies (Ayre, 2004, p. 
10). A University of Michigan study agrees with this sentiment concluding, "the main effect of the more restrictive settings [in these popular filtering products] is to block other categories of controversial material besides pornography" including LGBTIQ materials (Richardson et al., 2002, p. 2894).

Some recommendations are made in the Library Technology Report article "Filtering and Filtering Software" by Lori Bowen Ayre on how to deal with filtering mandates and work to lessen the damage done. She recommends disabling the monitoring feature available on many filtering products and to make this known to patrons so that they have a reasonable assurance that their privacy is maintained and that their online usage will not be documented (Ayre, 2004, p. 50). As mentioned earlier with the Kaiser survey, confidentiality ranked as the most important issue when adolescents look up health information online (Richardson et al., 2002, p. 10).

A second suggestion is to closely examine the category descriptions in the software product chosen. Many of the filtering products will hide exactly what URLs are blocked in a certain category so a librarian must be willing to investigate exactly what is contained in a category the filtering company self-defines as "sex" or "sexuality". For example, the two popular filtering products Smartfilter and N2H2 both have content categories called "Sex" yet Smartfilter's rate of overblocking health sites is much lower than N2H2's whose filter would block non-explicit sites dealing with adolescent sexuality (Ayre, 2004, p. 50). Essentially, a librarian should never trust the filtering company's category descriptions and should vigorously investigate the product's settings to attempt to lower the rate at which they block access to health and LGBTIQ information. Experimenting with the settings, and doing simulations, can prove beneficial.

Ayre continues with the recommendation that filters reinforce existing Internet use policy. For example, if the library's Internet use policy prohibits gambling, online gaming or 
chatting, the filtering software may have features that will block these services. Separate profiles can be made so that gambling, for example, could be blocked for everyone; whereas information about sexuality could be available via the teen profile in the teen library and blocked in the children's section (p. 51). Working closely with staff to create these profiles would be wise as they are often the best resources and will ultimately be the ones asked to turn off the filtering when it is blocking a requested site. Creating separate profiles enable libraries to comply with CIPA while demonstrating to their patrons that the library remains a safe place for young children to use the Internet (p. 52).

Ultimately, ensuring simple, and minimal, compliance with CIPA should be all that any librarian will need out of any prospective filtering product. As such, Ayre recommends that the librarian, or network administrator, who chooses the product and configures it keep in mind that compliance with CIPA is all that is necessary. Many popular filtering products used in libraries, such as CyberPatrol, contain broadly defined categories such as "adult/sexually explicit" which includes both materials that are objectionable, and sites that are not. Configuring the product to reasonably reduce the amount of overblocking will go a long way in reducing requests on staff (p. 53). Additionally, looking at usage studies, such as the one written by San Jose Public, may help a library system to choose an appropriate filtering product.

Another concern is the reliance on filtering once installed. Adult patrons with children may wrongly assume that because an Internet terminal is filtered this automatically results in a safer environment for children (Ayre, 2004, p. 54; Kranich, 2004, p. 14). Using specially designed search engines tailored towards sites appropriate for children may help, but a library should never put faith in filtering's ability to block all objectionable content from children. Accordingly, continuing to monitor the Internet viewing habits of very young patrons would be appropriate as long as adolescents have a reasonable degree of privacy and confidentiality. 
After choosing and configuring the complying filtering product, staff should do testing before patron use. Training library staff on how to disable the filtering and how to monitor the accuracy of the configuration is needed. Included in this process is a method for patron feedback and a clear explanation of the filtering policy and what exactly is blocked to the public. Ayre recognizes that anonymity is essential in this effort when it comes to both patron feedback and requests to unblock permitted sites. She warns, “[p]atrons don't always want to ask for help or disclose what they are looking for. The embarrassed teenager looking for sex education information that has been erroneously categorized as sexually explicit and thus blocked is not likely to request the page be unblocked. If patrons could make override requests anonymously, they might." (Ayre, 2004, p. 59). Libraries would thus be wise to create a procedure where patrons could anonymously submit that a particular site be unblocked from the filtering.

When handling these unblocking requests a library should create an effective procedure to handle them as quickly and fairly as possible. Waiting until the end of the week to evaluate unblock requests, or at a specific time every day, may be a poor way to ensure equitable access. Instead, either immediately evaluate a blocked site or, if this is not possible, create a policy to automatically unblock sites and evaluate them after the fact may be more appropriate (p. 60). Because of the rapidly changing nature of online sources, expediency is critical in ensuring that processing requests for non-objectionable materials is done as quickly as possible.

A library should also create a policy on the use of online social networks. As the interactivity of the Internet rises, it is becoming increasingly important that adolescents are given freedom to connect with their peers through social networking sites of their choosing. A blanket policy that restricts access to Facebook or MySpace, for example, may have detrimental effects on the ability of these adolescents to connect with others and create an online social network. 


\section{Conclusion}

While the current debate over Internet filtering remains unresolved, many libraries have little choice but to abide by the filtering restrictions mandated by the Children's Internet Protection Act. The ways in which filtering affects access to health information is clear, as is the disparate impact this mandate has on LGBTIQ youth. Internet filtering particularly affects LGBTIQ adolescents as it impairs their ability to create online communities and find healthy places to experiment during their crucial identity formation period. There is solid evidence that providing adolescents with the information they need to make informed choices about their sexuality and health, and environments conducive to their identity formation, leads to reductions in STD transmission, depression and teen suicide. It is a matter of public health that librarians remain proactive in combating Internet filtering and the issues of intellectual freedom it raises for sexual minority and gender variant patrons. Creating a clear and comprehensive Internet use policy and making a vigilant effort to reduce unnecessary overblocking will reflect the ideals of the profession and the values of intellectual freedom. Librarians have an important role in ensuring equitable access and providing critical health information to those in our communities who may be disadvantaged and unable to access this information elsewhere. 


\section{References}

ACLU v. Reno, 929 F.Supp. 824 (E.D.Pa. 1996)

ACLU v. Reno, 217 F.3d 162 (3rd Cir. 2000)

ALA freedom to read statement. [n.d.]. In American Library Association. Retrieved October 3, 2009 from http://www.ala.org/ala/aboutala/offices/oif/statementspols/ftrstatement/freedomreadstate $\underline{\text { ment.cfm }}$

American Psychological Association. (2008). Answers to your questions: For a better understanding of sexual orientation and homosexuality. Retrieved October 16, 2009 from http://www.apa.org/pubinfo/answers.html

Ayre, L.B. (2004). Filtering and filter software. Library Technology Reports, 40(2), 5-80.

Bell, B. (2001, March). Filth, filtering, and the First Amendment: Ruminations on public libraries' use of Internet filtering software. Federal Communications Law Journal, 53, 191-237.

Bernstein, G. (2004, April). Accommodating technological innovation: identity, genetic testing and the Internet. Vanderbilt Law Review, 57, 965-1039.

Bond, B., Hefner, V., \& Drogos, K. (2009). Information-seeking practices during the sexual development of lesbian, gay, and bisexual individuals: the influence and effects of coming out in a mediated environment. Sexuality \& Culture, 32(1), 32-50. doi:10.1007/s12119-008-9041-y

Brooks, Caryn. (2009, June 2). How to come out on Facebook. TIME Magazine. Retrieved November 10, 2009 from http://www.time.com/time/nation/article/0,8599,1901909,00.html.

Chermerinsky, E. (2006). Constitutional law : principles and policies. New York, NY: Aspen 
Publishers.

Deibert, R., Palfrey, J., Rohonzinski, R., \& Zittrain, J., (Eds.). (2008). Access denied: the practice and policy of global Internet filtering. Cambridge, MA: The MIT Press.

Denizet-Lewis, B. (2009, September 23). Coming out in middle school. New York Times. Retrieved October 3, 2009 from http://www.nytimes.com/2009/09/27/magazine/27outt.html.

Dobija, J. (2007). The first amendment needs new clothes. American Libraries, 38(8), 51-53.

Fedders, B. (2006, Spring). Coming out for kids: recognizing, respecting, and representing LGBTQ youth. Nevada Law Journal, 6, 774-804.

Friedman, C. \& Morgan, E. (2009). Comparing sexual minority and heterosexual young women's friends and parents as sources of support for sexual issues. Journal of Youth and Adolescence, 38, 920-936. doi:10.1007/s10964-008-9361-0

Garry, J.M., Javier, L., Schneider, K., Spear, J., Walsh, J., Clayton, G., Smith, G.A., et al. (1999). Access denied version 2.0: the continuing threat against internet access and privacy and its impact on the lesbian, gay, bisexual and transgender community. Retrieved November 1, 2004 from http://www.glaad.org/documents/media/AccessDenied2.pdf

Harris Poll Interactive. (2008, April 21). Gay and lesbian adults are reading and responding to more blogs than heterosexuals. Retrieved December 22, 2009 from http://www.harrisinteractive.com/news/allnewsbydate.asp?NewsID $=1300$

Hamer, J. (2003). Coming-out: gay males' information seeking. School Libraries Worldwide, $9(2), 73-89$.

Hammack, P., Thompson, E., \& Pilecki, A. (2009). Configuration of identity among sexual minority youth: context, desire, and narrative. Journal of Youth and Adolescence, 38, 
867-883. doi:10.1007/s10964-008-9342-3

Heins, M., Cho, C. \& Feldman, A. (2006). Internet filters: A public policy report. In Brennan Center for Justice, NYU School of Law. Retrieved June 2, 2009 from http://www.fepproject.org/policyreports/filters2.pdf.

Hostetler, A.J. \& Herdt, G.H. (1998). Culture, sexual lifeways, and developmental subjectivities: Rethinking sexual taxonomies. Social Research, 65, 249-290.

Houghton-Jan, S. (2008, April). Internet filtering software tests: Barracuda, CyberPatrol, FilterGate \& WebSense. In San Jose Public Library. Retrieved June 2, 2009 from http://www.sjlibrary.org/about/sjpl/commission/agen0208_report.pdf.

Internet Filtering Software. A position paper from the Office for Public Policy of the Gay, Lesbian and Straight Education Network. In GLSEN (Gay, Lesbian and Straight Education Network). Retrieved June 2, 2009, from http://www.glsen.org/binarydata/GLSEN_ATTACHMENTS/file/282-1.PDF

Jaeger, P., \& Yan, Z. (2009, March). One law with two outcomes: Comparing the implementation of CIPA in public libraries and schools. Information Technology and Libraries, 28(1), 6-14.

Kibble, M. (2008). Fear mongering, filters, the Internet and the First Amendment: Why Congress should not pass legislation similar to the Deleting Online Predators Act. Roger Williams University Law Review, 13, 497-528.

Kosciw, J.G., Diaz, E.M., \& Greytak, E.A. (2007). The 2007 national school climate survey : the experiences of lesbian, gay, bisexual and transgender youth in our nation's schools. In GLSEN (Gay, Lesbian and Straight Education Network). Retrieved November 10, 2009 from http://www.glsen.org/binarydata/GLSEN_ATTACHMENTS/file/000/001/1290-1.pdf. 
Kranich, N. (2004). Why filters won't protect children or adults. Library Administration and Management, 18(1), 14-8.

Mainstream Loudoun v. Loudoun County. 24 F. Supp. 2d 552 (E.D. Va. 1998).

McKenna, Y.A., \& Bargh, A. (1998). Coming out in the age of the Internet: identity "demarginalization" through virtual group participation. Journal of Personality and Social Psychology, 75(3), 681-694. doi:10.1037/0022-3514.75.3.681

Miller v. California, 413 U.S. 15 (1973).

Miltner, K. (2005, May). Discriminatory filtering: CIPA's effect on our nation's youth and why the Supreme Court erred in upholding the constitutionality of the Children's Internet Protection Act. Federal Communications Law Journal, 57, 555-578.

Munt, S., Bassett, E., \& O’Riordan, K. (2002, July). Virtually belonging: Risk, connectivity, and coming out on-line. International Journal of Sexuality and Gender Studies, 7(2/3), 125-137. doi:10.1023/A:1015893016167

Perry Education Association v. Perry Local Educators' Association, 460 U.S. 37 (1983)

Peters, R. (2007). It will take more than parental use of filtering software to protect children from Internet pornography. New York University Review of Law and Social Change, 31, 829-854.

Richardson, C.R., Resnick, P.J., Hansen, D.L., Derry, H.A., Rideout, V.J. (2002). Does pornography-blocking software block access to health information on the Internet? Journal of the American Medical Association, 288(22).

Rideout, V. (2002, December). See no evil: How Internet filters affect the search for online health information. In Henry J. Kaiser Family Foundation. Retrieved June 2, 2009 from http://www.kff.org/entmedia/upload/See-No-Evil-How-Internet-Filters-Affect-theSearch-for-Online-Health-Information-Executive-Summary.pdf. 
Schmidt, C. (2008, March). Those interfering filters! How to deal with the reality of filters in your school library. Library Media Connection, 26(6), 54-55.

Spurlin, C., \& Garry, P. (2009). Does filtering stop the flow of valuable information? A case study of the Children's Internet Protection Act (CIPA) in South Dakota. South Dakota Law Review, 54, 89-96.

Stein, E. (2003). Queers anonymous: Lesbians, gay men, free speech, and cyberspace. Harvard Civil Rights-Civil Liberties Law Review, 38, 159-213.

United States of America, et al., v. American Library Association, Inc., et al. 539 U.S. 194 (2003).

Van der Heide, J.C. (2008, Fall). Social networking and sexual predators: The case for selfregulation. Hastings Communications and Entertainment Law Review, 31, 173-191.

Wu, F. (2004). United States v. American Library Ass'n: The Children's Internet Protection Act, library filtering, and institutional roles. Berkeley Technology Law Journal, 19, 555583.

${ }^{1}$ See also the profile "It's Not Monopoly: Gender Role Explorations in Online Environments" in Section One of this book.

${ }^{2}$ For more information, see also "Queering Libraries and Classrooms in the United States and Canada: Strategies to Build Inclusive School and Public Library Collections and Services for Sexual Minority and Gender Variant Youth" in Section Seven of this book. 